\title{
Properties of reaction bonded silicon nitride obtained from slip cast preforms
}

\author{
J RAKSHIT and J MUKERJI* \\ Central Glass and Ceramic Research Institute, Jadavpur, Calcutta 700032, India
}

MS received 24 November 1990; revised 3 March 1990

\begin{abstract}
Fabrication of silicon preforms of high green density $\left(>1.2 \mathrm{~g} / \mathrm{cm}^{3}\right)$ by slip casting of silicon (in aqueous medium) has been studied. The nitridation product consists of $59-85 \% \alpha$ $\mathrm{Si}_{3} \mathrm{~N}_{4}, 7-22 \% \beta-\mathrm{Si}_{3} \mathrm{~N}_{4}$ and $7-23 \% \mathrm{Si}_{2} \mathrm{~N}_{2} \mathrm{O}$ phase. The amounts of un-nitrided silicon were negligible. The microstructure is either granular or consists of needle-like grains $\left(\alpha-\mathrm{Si}_{3} \mathrm{~N}_{4}\right)$ and whiskers deposited in the large pores. MOR values of the specimens are almost constant up to $1000^{\circ} \mathrm{C}$ or $1400^{\circ} \mathrm{C}$ or show slight increase up to $1000^{\circ} \mathrm{C}$ or $1200^{\circ} \mathrm{C}$. In some cases a little dip around $1200^{\circ} \mathrm{C}$, then a sharp increase in MOR up to $1400^{\circ} \mathrm{C}$ was observed. $K_{i c}$ values are almost constant up to $1000^{\circ} \mathrm{C}$, and thereafter increase sharply.

Pore size distribution, existence of $\mathrm{Si}_{2} \mathrm{~N}_{2} \mathrm{O}$ phase and oxidation of RBSN at high temperatures have been considered for the explanation of the observed behaviour.
\end{abstract}

Keywords. Reaction-bonded silicon nitride; slip cast silicon preforms.

\section{Introduction}

Slip casting or injection moulding via aqueous slip of silicon permits fabrication of complicated shapes (Parr and May 1967; Mclean 1982). Slip casting of silicon has been studied previously. The main problem in slip casting is to achieve high green density $\left(>1.2 \mathrm{~g} / \mathrm{cm}^{3}\right)$ in the cast body. The present study is related to (a) the study of slip casting of $\mathrm{Si}$ as regards silicon loading, $\mathrm{pH}$, ageing of the slip and casting time, and the effects of these on green density and (b) the effect of the possible formation of $\mathrm{SiO}_{2}$ layers on the reaction-bonded silicon nitride (RBSN) as regards phase composition, and its mechanical properties.

\section{Experimental}

Silicon lumps (low-calcium content) obtained from Indian-metals and Ferro-alloys, Bhubaneswar, were successfully ground to fine powder in a pulveriser and vibratory ball mill and particle of size less than $10 \mu \mathrm{m}$ were separated out by fractional sedimentation. An aqueous suspension of silicon at a $\mathrm{pH}$ of about 9 was allowed to settle for about $35 \mathrm{~min}$ (as obtained from a predetermined sedimentation curve) in a column of height $20 \mathrm{~cm}$, when all particles larger than $10 \mu \mathrm{m}$ settled. The particle size distribution was as follows, $14 \%$ between 10 and $5 \mu \mathrm{m}, 48 \%$ between 5 and $1 \mu \mathrm{m}$ and the rest $(38 \%)$ less than $1 \mu \mathrm{m}$. The specific surface area of this powder was $5.07 \mathrm{~m}^{2} / \mathrm{g}$ as determined by the BET nitrogen adsorption method (Micromerities, GA, USA) with an equivalent spherical diameter of $0.51 \mu \mathrm{m}$. Major impurities in the powder by weight \% were , Fe: 0.22; Al: 0.08; Ca: 0.004; Mg: 0.02 (Na + K): 0.09.

\footnotetext{
*For correspondence.
} 
Silicon billets of rectangular shape $\left(47 \times 21 \times 10 \mathrm{~mm}^{3}\right)$ were made by solid casting of silicon slips. A preliminary experiment on the sedimentation of silicon particles from its suspension was carried out using sedimentation balance in the $\mathrm{pH}$ range of 3-11. Silicon suspension was made using $50 \mathrm{~g}$ of silicon in distilled water with $\mathrm{Na}$-alginate ( $1 \%$ by weight of silicon) solution as a defloculating agent. The amount of silicon deposited was directly read out from a Mettler balance (Mettler ME 100). Acidic and alkaline $\mathrm{pH}$ levels of the suspension were maintained using $\mathrm{HCl}$ and liquid ammonia solutions respectively.

For solid casting, a silicon slip of $\mathrm{pH}$ around 9 was made, having a silicon to water weight ratio of $5: 6$ to 5:7, and an ageing time of 5 to 7 days. Air bubbles were removed by keeping the slip in a vacuum dessicator. Casting was carried out in a plaster mould.

A laboratory-made sintered alumina-tube furnace capable of working in a controlled atmosphere was used for nitridation. Iolar-2 grade nitrogen gas supplied by Indian Oxygen and containing $4 \mathrm{ppm}$ each of $\mathrm{O}_{2}$ and $\mathrm{H}_{2} \mathrm{O}$ and $1 \mathrm{ppm}$ of the oxide of carbon was used for nitridation. A typical nitridation schedule was $24 \mathrm{~h}$ at $1200^{\circ} \mathrm{C}, 24-28 \mathrm{~h}$ at $1300^{\circ} \mathrm{C}$ and $20-24 \mathrm{~h}$ at $1350^{\circ} \mathrm{C}$, followed by $10-16 \mathrm{~h}$ at $1380^{\circ} \mathrm{C}$.

Bulk density as well as \%-pore (open) volume of nitrided specimens were determined. Poresize distributions of RBSN specimens were determined using a 'Mercury Intrusion porosimeter' (Micromerities, USA, Model No. 1300). Microstructures of fired samples were examined by both optical and scanning electron microscopy. For optical microscopy, polished sections were prepared by mounting the sample in epoxy and grinding successively with -220 mesh and -400 mesh $\mathrm{SiC}$ powder followed by -600 mesh emery. Polishing was done with 20 micron and then 5 micron $\mathrm{Al}_{2} \mathrm{O}_{3}$ powder on felt in a vibratory polisher. The fracture surface was examined by SEM after gold coating. Flexural strength (room temperature and high temperature) was measured using 4-point flexural specimens of $45 \times 4.5 \times 3.5 \mathrm{~mm}^{3}$ size. Silicon nitride fixtures were used for sample support (Mukerji et al 1985). Fracture toughness was measured using a single edge notched beam specimen in 4-point geometry, having a notch-width of 0.2 to $0.3 \mathrm{~mm}$. The normalised notch width $(a / w)$ was in the range 0.3 to $0 \cdot 5$. Fracture toughness $\left(K_{i c}\right)$ was determined using the equation recommended by ASTM (Brown and Srawley 1966).

\section{Results and discussion}

\subsection{Green and fired densities}

The green-density $\left(D_{g}\right)$, fired density $\left(D_{f}\right)$, nitriding temperature, \% weight gain and porosity, as determined by the water absorption method, are given in table 1 . The $D_{g}$ of cast products was found to depend on the ageing time, casting time and $\mathrm{pH}$ of the silicon suspension. Results are shown in tables 2 and 3. The results of the sedimentation experiments at different $\mathrm{pH}$ values are shown in figure 1 . From the curve of figure 1, a graph is plotted for sedimentation rate vs $\mathrm{pH}$ (figure 2). It is evident that better suspension can be expected at $\mathrm{pH} 4$ and $\mathrm{pH}$ 9. The suspension is least stable at a $\mathrm{pH}$ around 2 and 12 (figure 2). Accordingly, casting time is less $(\sim 50 \mathrm{~min})$ and the rate of casting is fast for the silicon suspension of high acidic $(\mathrm{pH}<3)$ or high alkaline $(\mathrm{pH}>10)$ medium. A longer casting time $(>3 \mathrm{~h})$ was observed for a slip of $\mathrm{pH}$ range 7.5 to $10 \cdot 5$. The longer casting-time of a particular slip favours higher green 
Table 1. Properties of green compacts and nitrided products after firing at $1380^{\circ} \mathrm{C}$ under Iolar II $\mathrm{N}_{2}$ gas atmosphere.

Particle size $<10 \mu \mathrm{m}$

\begin{tabular}{lcccc}
\hline Sample & $\begin{array}{c}D_{g} \\
\left(\mathrm{~g} / \mathrm{cm}^{3}\right)\end{array}$ & $\begin{array}{c}D_{f} \\
\left(\mathrm{~g} / \mathrm{cm}^{3}\right)\end{array}$ & $\begin{array}{c}\text { Weight } \\
\text { gain }(\%)\end{array}$ & $\begin{array}{c}P^{*} \\
(\%)\end{array}$ \\
\hline $\mathbf{S}_{1}$ & 1.28 & 2.08 & $51 \cdot 2$ & 28.2 \\
$\mathbf{S}_{2}$ & 1.36 & $2 \cdot 16$ & $51 \cdot 3$ & 26.1 \\
$\mathbf{S}_{3}$ & 1.35 & 2.25 & 52.6 & 22.0 \\
$\mathbf{S}_{4}^{\dagger}$ & 1.39 & 2.34 & 56.1 & 17.7 \\
$\mathbf{S}_{5}^{\dagger}$ & 1.45 & 2.48 & 54.4 & 14.8 \\
\hline
\end{tabular}

*Argon treatment before nitridation

* I ore (open) volume.

Table 2. Dependence of green density of the 'slip-cast' specimens on 'casting time' and 'ageing time'.

Starting silicon powder $<10 \mu \mathrm{m} ; \mathrm{pH}$ of the slip is approximately 9 .

\begin{tabular}{lccc}
\hline $\begin{array}{l}\text { Ageing time } \\
\text { (days) }\end{array}$ & $\begin{array}{c}\text { Casting time } \\
(\mathrm{min})\end{array}$ & $\begin{array}{c}\text { Water/silicon } \\
\text { ratio (by wt) }\end{array}$ & $\begin{array}{c}\text { Green density } \\
\left(\mathrm{g} / \mathrm{cm}^{3}\right)\end{array}$ \\
\hline 1 & 80 & 1.3 & 1.22 \\
1 & 300 & 1.4 & 1.30 \\
3 & 130 & 1.3 & 1.28 \\
3 & 140 & 1.3 & 1.32 \\
4 & 110 & 1.4 & 1.25 \\
4 & 140 & 1.4 & 1.26 \\
5 & 145 & 1.4 & 1.31 \\
5 & 180 & 1.4 & 1.40 \\
6 & 75 & 1.4 & 1.20 \\
6 & 300 & 1.4 & 1.44 \\
7 & 135 & 1.3 & 1.40 \\
7 & 300 & 1.4 & 1.45 \\
\hline
\end{tabular}

Table 3. Dependence of "casting time' and 'green density" on the $\mathrm{pH}$ of the silicon slip.

Silicon particle size $<10$ micron

\begin{tabular}{lccc}
\hline $\begin{array}{l}\text { pH of the } \\
\text { slip }\end{array}$ & $\begin{array}{c}\text { Casting time } \\
\text { (min) }\end{array}$ & $\begin{array}{c}\text { Water/silicon } \\
\text { ratio (by wt.) }\end{array}$ & $\begin{array}{c}\text { Green density } \\
\left(\mathrm{g} / \mathrm{cm}^{3}\right)\end{array}$ \\
\hline 1.9 & 17 & 1.4 & 1.14 \\
2.9 & 50 & 1.4 & 1.19 \\
4.2 & 150 & 1.4 & 1.22 \\
5 & 195 & 1.4 & 1.20 \\
7.5 & 255 & 1.4 & 1.28 \\
8 & 300 & 1.5 & 1.30 \\
9 & 135 & 1.3 & 1.40 \\
9 & 300 & 1.4 & 1.45 \\
9.4 & 220 & 1.5 & 1.29 \\
10 & 250 & 1.5 & 1.23 \\
10.4 & 180 & 1.5 & 1.19 \\
11.2 & 75 & 1.4 & 1.16 \\
\hline
\end{tabular}




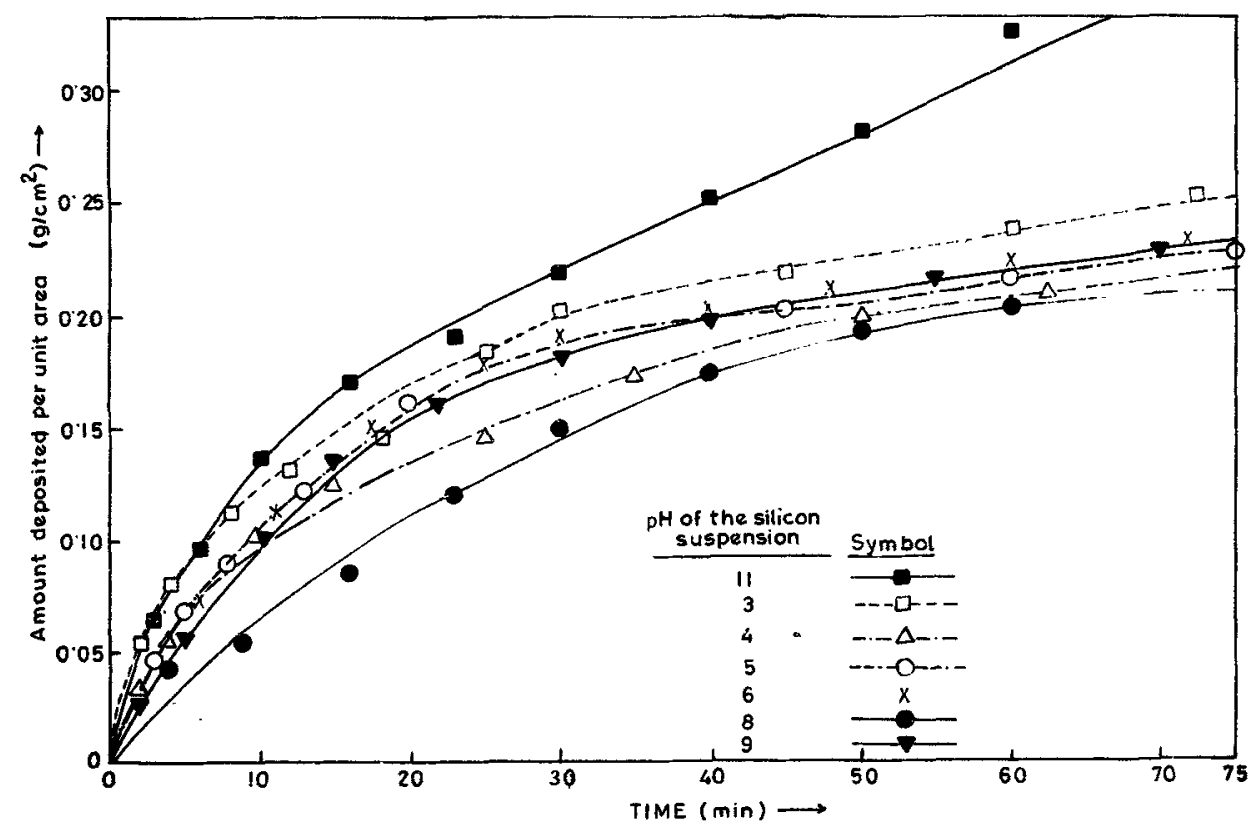

Figure 1. Amount of deposition of silicon particle per unit area $\left(\mathrm{g} / \mathrm{cm}^{2}\right)$ from silicon suspension (Si particle size $<10 \mu \mathrm{m}$ )

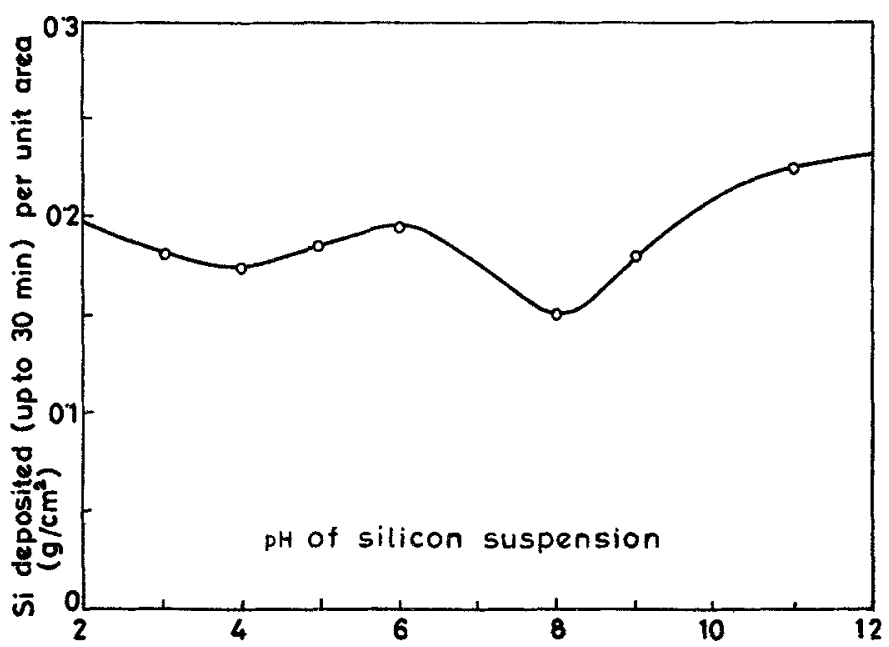

Figure 2. Dependence of silicon particle sedimentation on the $\mathrm{pH}$ of the suspension.

density as the particles also get a chance to distribute themselves in the voids. An optimum green density was observed for a slip having a silicon-water weight ratio of $5: 6$ to $5: 7$, an ageing time of 5 to 7 days and a pH of about 9 .

\subsection{Weight gain on nitridation}

A nitridation weight gain of $51-56 \%$ was achieved, the theoretical weight gain being $66.6 \%$. The optical microscopic as well as XRD of the nitrided specimens showed 
Table 4. Type and amount of phases present in slip cast RBSN.

\begin{tabular}{lcccc}
\hline & \multicolumn{4}{c}{ Approximate amount of phases present (wt. \%) } \\
\cline { 2 - 4 } Sample & $\alpha-\mathrm{Si}_{3} \mathrm{~N}_{4}$ & $\beta-\mathrm{Si}_{3} \mathrm{~N}_{4}$ & $\mathrm{Si}_{2} \mathrm{~N}_{2} \mathrm{O}$ & Free-Si \\
\hline $\mathrm{S}_{1}$ & $78 \cdot 6$ & $7 \cdot 3$ & $13 \cdot 1$ & 1 \\
$\mathrm{~S}_{2}$ & 63 & $14 \cdot 2$ & $22 \cdot 8$ & - \\
$\mathrm{S}_{3}$ & 59 & $21 \cdot 3$ & $19 \cdot 7$ & - \\
$\mathrm{S}_{4}$ & $84 \cdot 1$ & $9 \cdot 1$ & 6.8 & - \\
$\mathrm{S}_{5}$ & $80 \cdot 6$ & 11 & $8 \cdot 4$ & - \\
\hline
\end{tabular}

negligible amounts of unnitrided silicon. The low weight gain may be accounted for by the formation of $\mathrm{Si}_{2} \mathrm{~N}_{2} \mathrm{O}$ during nitridation, which needs $50 \%$ uptake of nitrogen as comparcd to $66.6 \%$ for nitride formation. The formation of oxynitride is expected to be due to the reaction between nitrogen and silica layers on the surface of silicon particles. During the ageing of the slip for long periods fine silicon particles produce $\mathrm{SiO}_{2}$ in the following way:

$$
\mathrm{Si}+2 \mathrm{H}_{2} \mathrm{O}=\mathrm{SiO}_{2}+2 \mathrm{H}_{2}
$$

It was shown (Atkinson and Moulson 1976) that any native oxide layer on silicon particles can be removed by heat treatment under vacuum or under argon atmosphere when the following reaction takes place.

$$
\mathrm{SiO}_{2}(\mathrm{~s})+\mathrm{Si}(\mathrm{S}, \mathrm{l}) \longrightarrow 2 \mathrm{SiO}(\mathrm{g})
$$

Thus a slipcast RBSN of higher weight gain (table 1) was achieved when argon treatment before nitridation was done, consequently the oxynitride phase was reduced from $23 \%$ to $7 \%$.

\subsection{Crystallographic phases}

Quantitative phase estimation was carried out using the calibration curve of Jack and Thomson in which the XRD peak height ratio of $\beta(210) /\{\beta(210)+\alpha(201)\}$ was directly plotted against weight $\% \beta$. The amount of free silicon and $\mathrm{Si}_{2} \mathrm{~N}_{2} \mathrm{O}$ were determined from a similar calibration curve using the peak height ratio of $\mathrm{Si}$ $(111) /\{\mathrm{Si}(111)+\alpha(201)\}$ and $\mathrm{Si}_{2} \mathrm{~N}_{2} \mathrm{O}(201) /\left\{\mathrm{Si}_{2} \mathrm{~N}_{2} \mathrm{O}(201)+\alpha(210)\right\}$ respectively. The type and amount of phases present are shown in table 4 . The major crystalline phase was $\alpha-\mathrm{Si}_{3} \mathrm{~N}_{4}$. It was stated earlier that unconverted silicon could not be found either by optical microscopic observation or by XRD, but appreciable amounts $(7-23 \%)$ of silicon oxynitride were detected and its existence has already been discussed in $\S 3 \cdot 2$.

\subsection{Porosity and pore-size distribution}

The total volume \% porosity (open) as measured by the water absorption method is shown in table 1. The result of the pre-size distribution as measured by a Mercury Intrusion porosimeter is shown in figure 3 . It is evident that about $962 \%$ of the pores lie between 0.2 and $0.008 \mu \mathrm{m}, 3.8 \%$ pores are greater than $0.2 \mu \mathrm{m}$. Pore-size distribution depends on green $\left(D_{g}\right)$ and fired density $\left(D_{f}\right)$ of the nitrided products. For a 


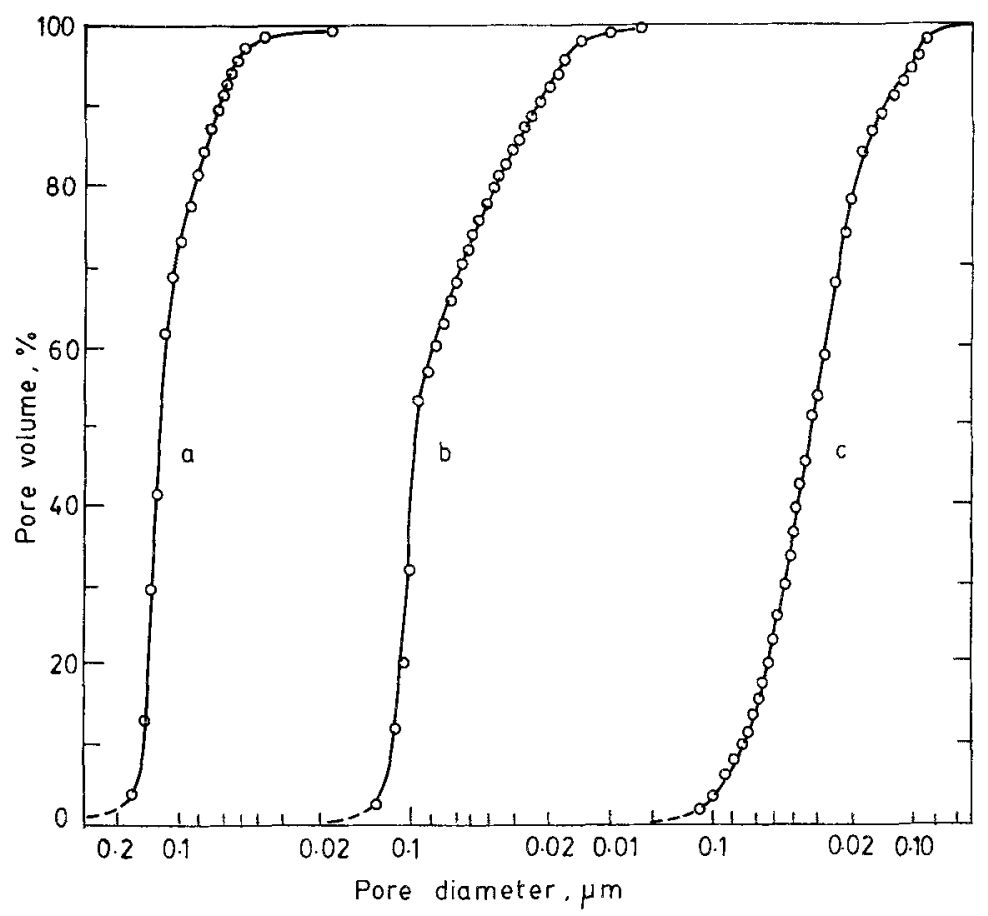

Figure 3. Pore-size distribution of RBSN samples. (a) $S_{3}$, (b) $S_{4}$ and (c) $S_{5}$.

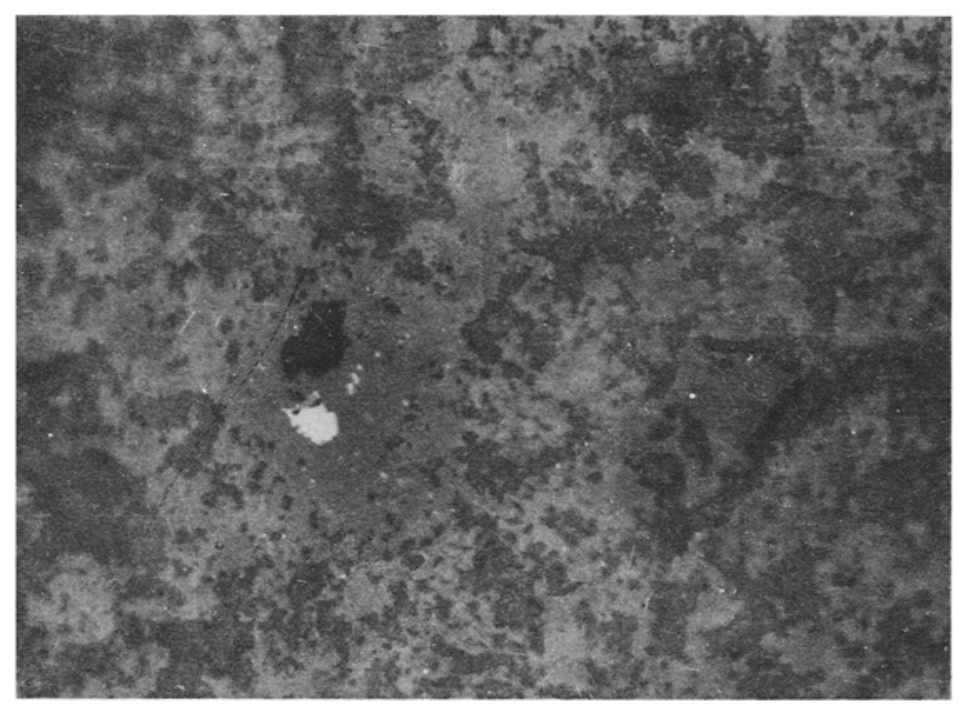

Figure 4. Optical micrograph of slip-cast RBSN showing negligible amount of free silicon $(\times 280)$.

sample $\left(\mathrm{S}_{3}\right)$ of $D_{g}-1.35 \mathrm{~g} / \mathrm{cm}^{3}$, and $D_{f}-2.25 \mathrm{~g} / \mathrm{cm}^{3}$, although $90 \%$ pores lie between 0.18 and 0.06 microns, most of the pores $(\sim 70 \%)$ are larger in size $(>0.1$ micron) (figure 3a). Large pores $\left(>0.1\right.$ micron) are also found in another sample $\left(S_{4}\right)$ of about $50 \%$ with a higher density (figure $3 \mathrm{~b})\left(D_{g}-1.39 \mathrm{~g} / \mathrm{cm}^{3}\right.$ and $\left.D_{f}-2.34 \mathrm{~g} / \mathrm{cm}^{3}\right)$. In a sample 
$\left(\mathrm{S}_{5}\right)$ of much higher $D_{g}\left(1.49 \mathrm{~g} / \mathrm{cm}^{3}\right)$ and $D_{f}\left(2.48 \mathrm{~g} / \mathrm{cm}^{3}\right)$, most of the pores $(\sim 80 \%)$ are fine and lie between 0.06 and 0.007 microns, while large pores $(>0.1$ micron) are only $3 \%$ (figure $3 \mathrm{c}$ ). Therefore fine pores are in higher percentage for products of higher green and nitrided density.

\subsection{Microstructure}

An optical micrograph of an RBSN specimen is shown in figure 4 showing negligible amounts of free silicon in the silicon nitride matrix, the scanning was done from the edge to the core. The material is composed of a continuous silicon-nitride phase with fine isolated pores. The scanning electron microscope (SEM) photographs of nitrided specimens are shown in figures $5 \mathrm{a}-\mathrm{e}$. The microstructure of $S_{3}$ in low magnification shows fine and uniformly distributed pores (figure 5a). At high magnification the microstructure is essentially granular in nature with complete absence of wool and whiskers (figure $5 \mathrm{~b}$ ). The material is composed of about $20 \% \mathrm{Si}_{2} \mathrm{~N}_{2} \mathrm{O}$, the $\alpha$-phase as detected by XRD is also low $(59 \%)$. The $\beta-\mathrm{Si}_{3} \mathrm{~N}_{4}$ phase was $21 \%$. A few large grains of $\beta-$ $\mathrm{Si}_{3} \mathrm{~N}_{4}$ with a few large pores (>1 micron) are also found in the microstructure (figure $5 b$ ). The sample $\left(\mathrm{S}_{4}\right)$ has got a preponderence of elongated $\alpha$-crystal and whisker deposit in the pores (figures $5 \mathrm{c}$ and d), large pores favour the deposition of $\alpha-\mathrm{Si}_{3} \mathrm{~N}_{4}$ whiskers and wool as these are formed essentially by vapour-transport; hence the $\alpha$ phase was present to a larger extent $(\sim 84 \%)$, compared to $\beta(\sim 9 \%)$ and $\mathrm{Si}_{2} \mathrm{~N}_{2} \mathrm{O}(\sim 7 \%)$. The microstructure of the dense product $\left(\mathrm{S}_{5}\right)$, with $80 \%$ pores of less than 0.06 micron, is essentially grainy with some whiskers deposited in the large pores (figures $5 \mathrm{e}$ and $\mathrm{f}$ ). The lower total porosity and grainy structure are responsible for the high room temperature flexural strength.

\subsection{Mechanical properties}

\section{6a Transverse rupture strength}

The four-point bending strength ( $\sigma$ ) of RBSN samples (table 5) is found to increase exponentially with bulk density both at room temperature and high temperature $\left(1200^{\circ} \mathrm{C}\right)$. Although increase in green density and nitridation weight gain are means of increasing nitrided density (and hence strength), it is very difficult to achieve a fired density of above $2.5 \mathrm{~g} / \mathrm{cm}^{3}$, because fired density depends on green density and a green density of above $1.45 \mathrm{~g} / \mathrm{cm}^{3}$ is very difficult to achieve by solid casting of silicon slip.

Figure 6 shows the flexural strength of RBSN samples and its variation with temperature. Some of the specimens $\left(S_{3}, S_{4}\right)$ show a rise in MOR with temperature, others $\left(S_{1}, S_{5}\right)$ show temperature independent values up to $1000^{\circ} \mathrm{C}$. The former observation is similar to those observed by Ashcroft (1973) and Paar and May (1967) and the latter to those by Thomson and Pratt (1966) and Jennings et al (1978). A sharp increase in MOR above $1200^{\circ} \mathrm{C}$ followed by a dip at that temperature is observed for the samples $S_{1}$ and $S_{3}$, but the constancy in values above $1200^{\circ} \mathrm{C}$ is found to be maintained by the specimen $\left(S_{5}\right)$ with high density $\left(2.48 \mathrm{~g} / \mathrm{cm}^{3}\right)$. A decreasing trend in MOR above $1200^{\circ} \mathrm{C}$ is found for sample $S_{4}$. Above observations are identical with the work of Evans and Davidge (1970), Noakes and Pratt (1972) and Davidge et al (1972). Oxidation, pore-size distribution and microstructure of RBSN have been considered 


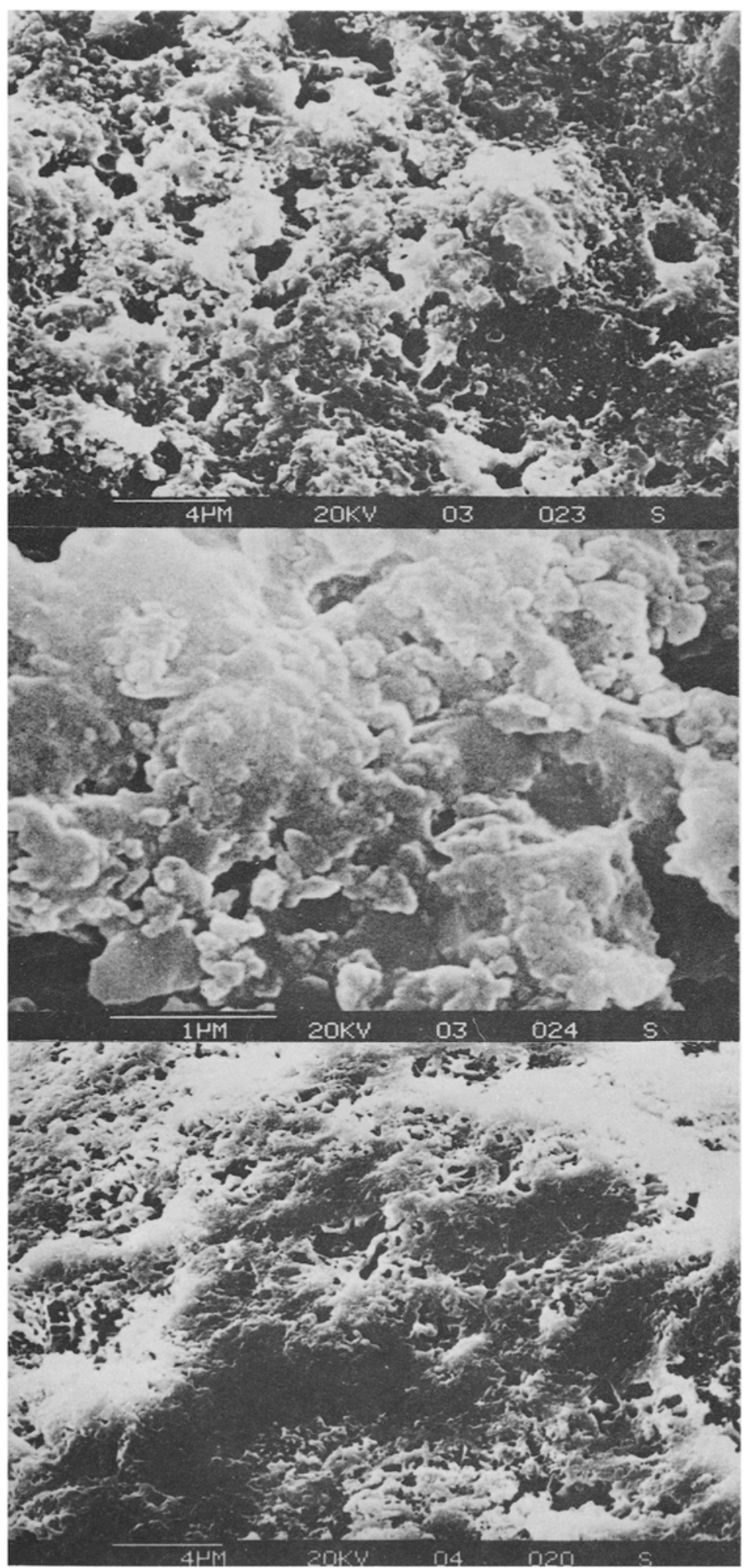

(a)

(b)

(c)

Figure 5. a. SEM photograph of the fracture-surface of $S_{3}$ showing finely distributed pores. b. SEM photograph of the fracture surface of $S_{3}$ showing granular structure. c. SEM photograph of the fracture surface of $\mathrm{S}_{4}$ showing needle like crystal and whisker. d. SEM 

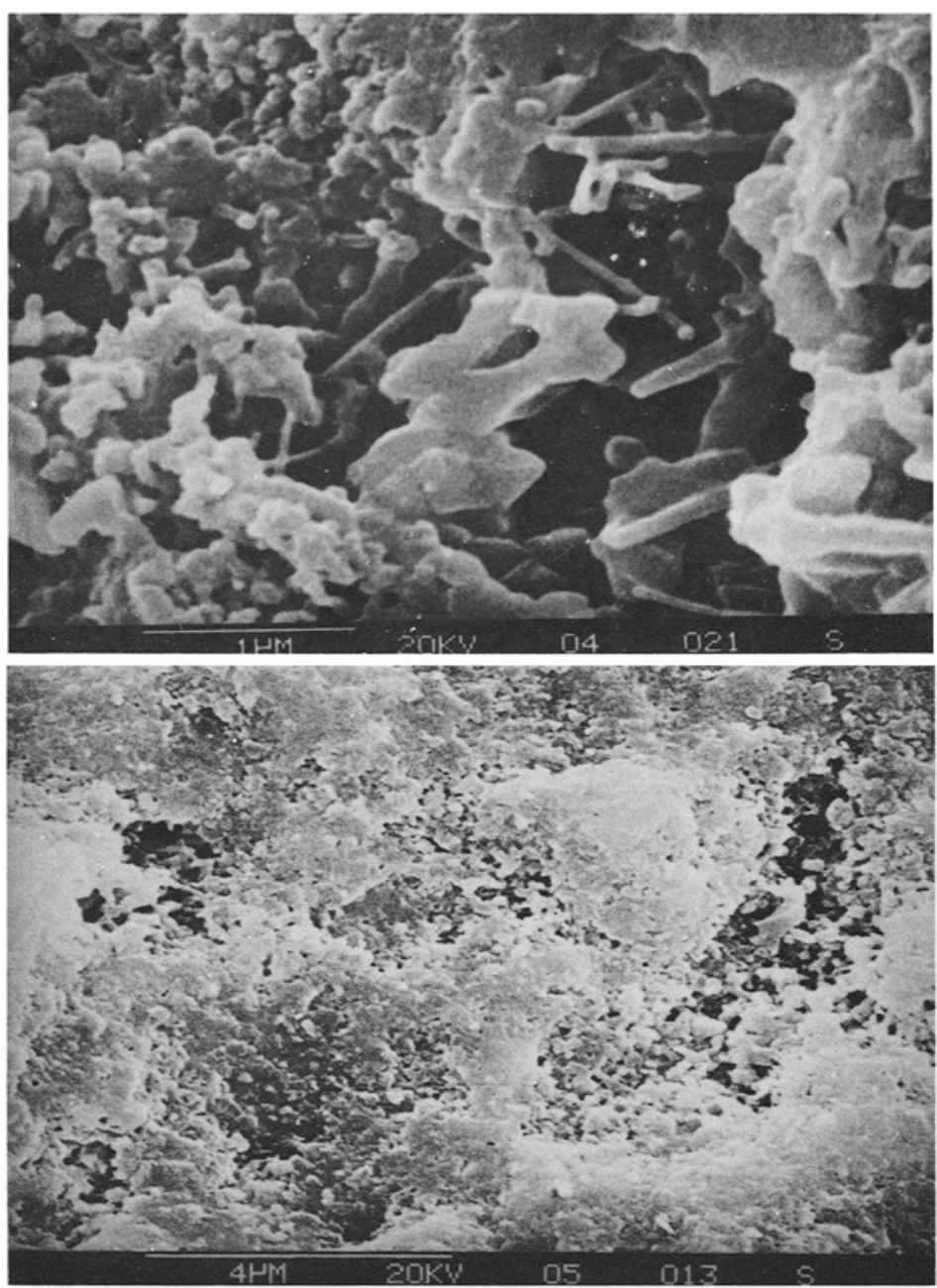

(e)

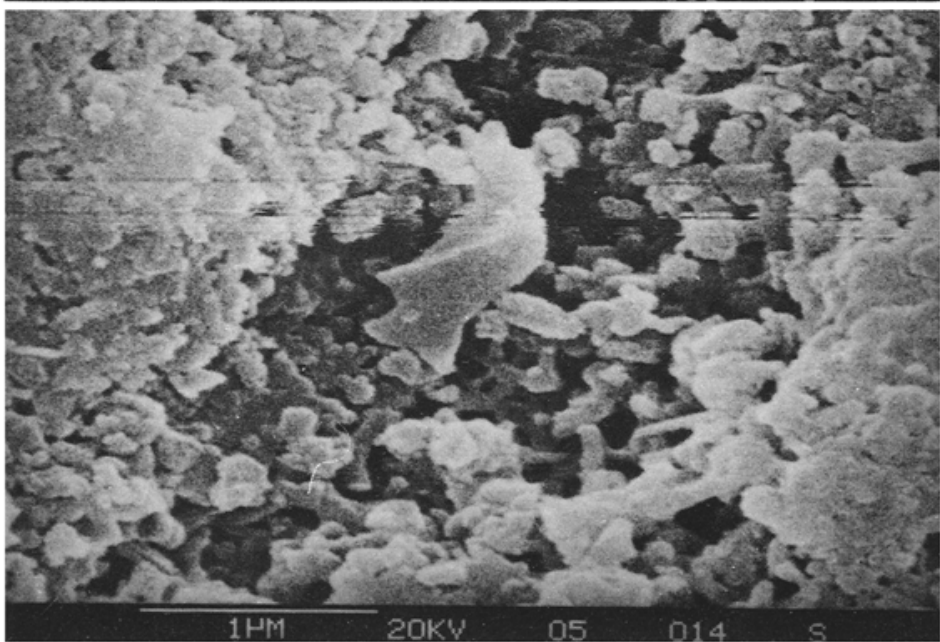

(d)

photograph of the fracture surface of $S_{4}$ in high magnification. e. SEM photograph of the fracture surface of $S_{5}$ showing granular structure with some amounts of whisker in the large pores. $f$. SEM photograph of the fracture surface of $S_{5}$ in high magnification. 
Table 5. Room temperature (RT) and high temperature $\left({ }^{\circ} \mathrm{C}\right)$ flexural strength (4-point) data of slip cast RBSN specimens.

Starting silicon powder $<10 \mu \mathrm{m}, D_{f}$ - fired density.

\begin{tabular}{|c|c|c|c|c|c|c|c|}
\hline \multirow[b]{2}{*}{ Sample } & \multirow{2}{*}{$\underset{\left(\mathrm{g} / \mathrm{cm}^{3}\right)}{\mathbf{D}_{f}}$} & \multicolumn{4}{|c|}{ Flexural strength (MPa) at } & \multirow{2}{*}{$\begin{array}{l}\text { Span } \\
(\mathrm{mm})\end{array}$} & \multirow{2}{*}{$\begin{array}{l}(\alpha: \beta) \\
\text { ratio }\end{array}$} \\
\hline & & RT & 1000 & 1200 & 1400 & & \\
\hline$S_{1}$ & 2.08 & $82 \cdot 0$ & $79 \cdot 0$ & 75.0 & $95 \cdot 0$ & $40-20$ & $10 \cdot 76$ \\
\hline $\mathrm{S}_{3}$ & $2 \cdot 25$ & 1520 & 174.0 & 172.0 & 1880 & $40-20$ & $2 \cdot 76$ \\
\hline $\mathrm{S}_{4}$ & $2 \cdot 34$ & $119^{*}$ & $136 \cdot 7^{*}$ & $139 \cdot 7^{*}$ & $114 \cdot 7 *$ & $20-7$ & $9 \cdot 24$ \\
\hline $\mathrm{S}_{5}$ & $2 \cdot 48$ & $197 \cdot 3^{*}$ & - & $195 \cdot 1^{*}$ & - & $20-7$ & $7 \cdot 32$ \\
\hline
\end{tabular}

$* 85 \%$ of the value obtained when $\operatorname{span}=20-7 \mathrm{~mm}(15 \%$ reduction $)$

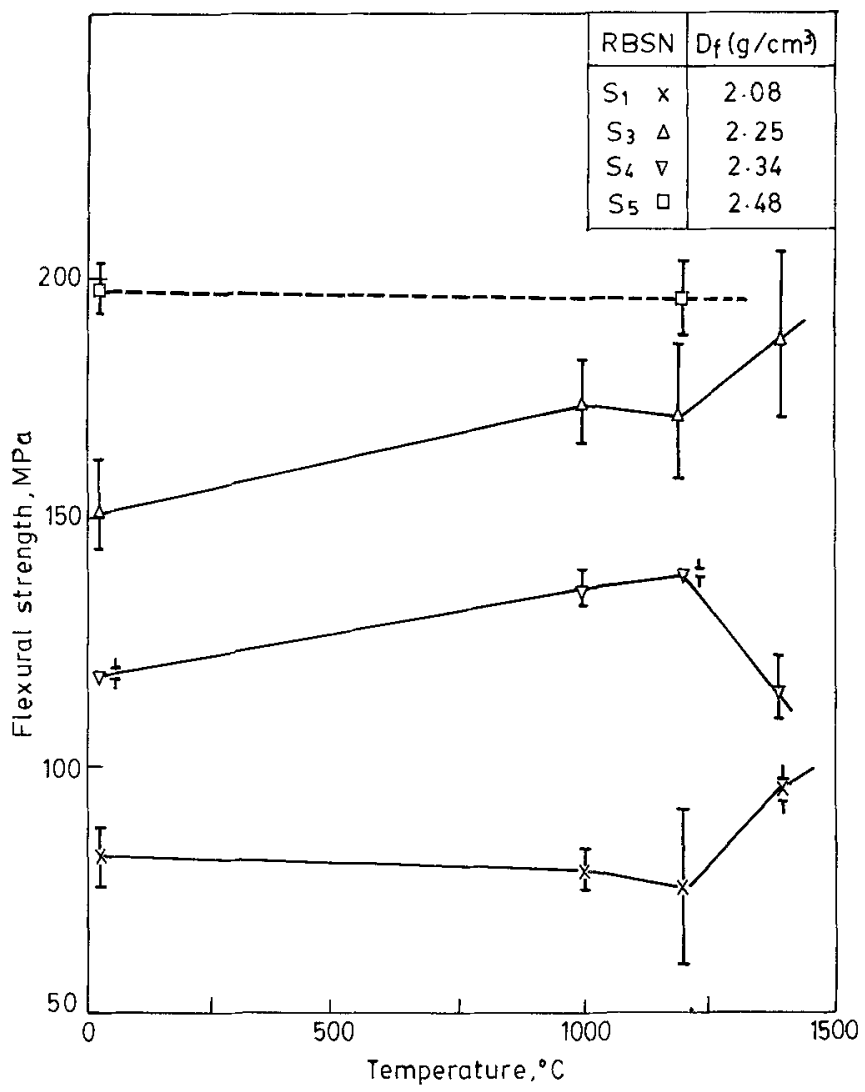

Figure 6. Dependence of flexural strength of slip-cast RBSN on temperature.

for the explanation of the above behaviour. Increase in strength with temperature is attributed to crack-healing by oxidation at the crack-tip. When the pores are very fine (as for the sample $\mathrm{S}_{5}$ ) extensive oxidation is not possible because of the sealing of pores. No crack-healing would be possible at high temperature, hence no increase in strength with temperature is observed. The decrease in strength above $1200^{\circ} \mathrm{C}$ is due to viscous 


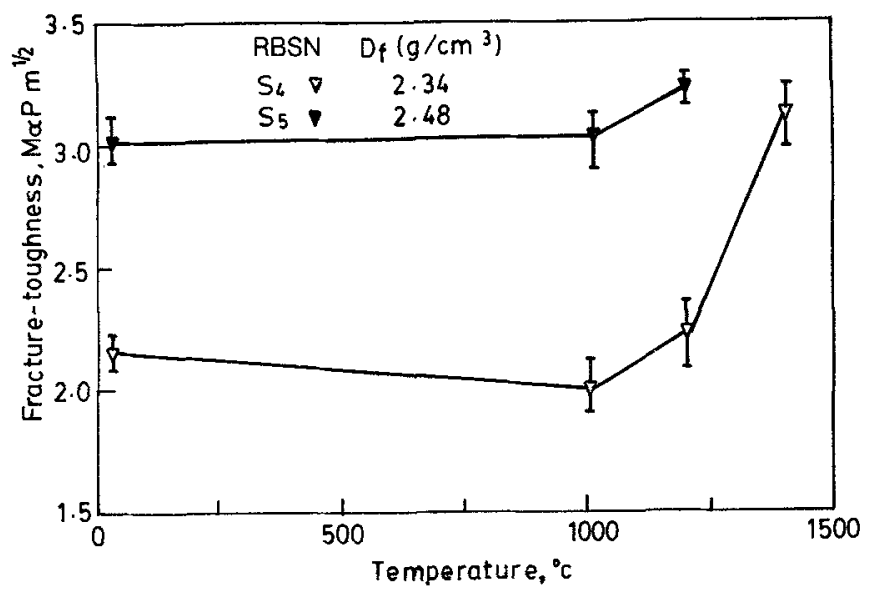

Figure 7. Dependence of fracture toughness $\left(K_{i c}\right)$ of slip cast RBSN on temperature.

Table 6. Room temperature $(\mathrm{RT})$ and high temperature $\left({ }^{\circ} \mathrm{C}\right)$ fracture toughness $\left(K_{i c}\right)$ SENB4-point bending data of slip cast RBSN.

Si powder $<10 \mu \mathrm{m}$.

\begin{tabular}{|c|c|c|c|c|c|c|}
\hline \multirow[b]{2}{*}{ Sample } & \multirow{2}{*}{$\underset{\left(\mathrm{g} / \mathrm{cm}^{3}\right)}{D_{f}}$} & \multicolumn{4}{|c|}{ Fracture toughness $\left(K_{c}\right)$ in $\mathrm{MPa} \mathrm{m}{ }^{1 / 2}$ at } & \multirow{2}{*}{$\begin{array}{l}\text { Span } \\
(\mathrm{mm})\end{array}$} \\
\hline & & RT & 1000 & 1200 & 1400 & \\
\hline$S_{4}$ & $2 \cdot 34$ & $2 \cdot 15$ & $2 \cdot 01$ & $2 \cdot 24$ & $3 \cdot 14$ & $20-7$ \\
\hline $\mathrm{S}_{5}$ & $2 \cdot 48$ & 3.04 & 3.02 & $3 \cdot 26$ & 一 & $20-7$ \\
\hline
\end{tabular}

flow of the grain boundary vitreous silica (Mukerji and Rakshit 1988). The sharp increase in strength above $1200^{\circ} \mathrm{C}$ for samples $\mathrm{S}_{1}$ and $\mathrm{S}_{3}$ is assumed to be due to the existence of high $\mathrm{Si}_{2} \mathrm{~N}_{2} \mathrm{O}(\sim 20 \%)$ in the nitrided products. There must be some influence of $\mathrm{Si}_{2} \mathrm{~N}_{2} \mathrm{O}(\sim 20 \%)$ on high temperature strength, because this behaviour is not found for samples $\left(\mathrm{S}_{4}, \mathrm{~S}_{5}\right)$ containing low $\mathrm{Si}_{2} \mathrm{~N}_{2} \mathrm{O}(<9 \%)$ (Mukerji et al 1985). The reason for the dip is not clear. A high room temperature MOR (197.3 MPa) is observed for the specimen of density $2.48 \mathrm{~g} / \mathrm{cm}^{3}$ having a granular structure and lower porosity $(14.8 \%$ ). This result is superior to those observed by others (Davidge et al 1972), but inferior to that of Heinrich (1987).

\section{$3.6 \mathrm{~b}$ Fracture toughness $\left(K_{i c}\right)$}

Dependence of fracture toughness on temperature is shown in figure 7, for two slip-cast RBSN specimens $\left(S_{4}\right.$ and $\left.S_{5}\right)$. The data is given in table 6. Like MOR, room temperature $K_{i c}$ values are higher for samples of higher bulk density. $K_{i c}$ values are found to be almost constant or decrease slightly up to $1000^{\circ} \mathrm{C}$ for both samples $\left(S_{4}\right.$ and $\left.S_{5}\right)$, thereafter an increasing trend is observed. The room temperature and high temperature $\left(1200^{\circ} \mathrm{C}\right) K_{i c}$ of slip-cast RBSN of density $2.48 \mathrm{~g} / \mathrm{cm}^{3}$ are 3.04 and $3.26 \mathrm{MPa}^{\mathrm{mi} / 2}$ respectively and the result is comparable to that obtained by Barnby and Taylor (1972), 
and superior to those observed by others (Thompson and Pratt 1966; Heinrich 1987; Burne and Tressler 1980). Increase in $K_{i c}$ may be the effect of oxidation at the crack tip. The role of presence of $\mathrm{Si}_{2} \mathrm{~N}_{2} \mathrm{O}$ on the increase in $K_{i c}$ cannot be explained at present.

\section{Conclusions}

(i) Fabrication of green-shape formation by solid casting, the criteria of silicon-slip to improve the density of the cast products and the properties of nitrided products have been described.

(ii) Total volume \% porosity (open) and pore-size distribution are dependent on green and fired densities of RBSN specimens. High percentages of fine pores are found in specimen with high bulk density.

(iii) Microstructures are grainy as well as needle-like crystals with whiskers and wool in the large pores. Specimens with grainy structure and fine pores show better room temperature flexural strength.

(iv) MOR values are either constant up to $1000^{\circ} \mathrm{C}$ or $1400^{\circ} \mathrm{C}$ or show a rise with rise of temperatures up to $1000^{\circ} \mathrm{C}$ with a dip at $1200^{\circ} \mathrm{C}$, then rising sharply above $1200^{\circ} \mathrm{C}$. This behaviour is explained by oxidation induced crack-healing, the existence of the silicon-oxynitride phase and the pore-size distribution of specimens which control the oxidation.

(v) The $K_{i c}$ values are almost constant up to $1000^{\circ} \mathrm{C}$, thereafter increase with increasing temperature. The oxidation product of silicon nitride at high temperature, existence of a silicon oxynitride phase and the absence of free silicon are assumed responsible for the above behaviour.

\section{References}

Ashcroft W 1973 Proc. Br. Ceram. Soc. 22169

Atkinson A and Moulson A J 1976 Sci. Ceram. 8111

Barnby J T and Taylor R A 1972 Special Ceram. 5 (ed.) Popper (UK: British Ceramic Research Association) p. 311

Brown W F and Srawley J E 1966 ASTM Spec. Tech. Publ. No. 410

Burne W C and Tressler R E 1980 Am. Ceram. Soc. Bull. 59443

Davidge R W, Evans A G, Gilling D and Willyman P R 1972 Special Ceram. 5 (ed.) Popper p. 329

Evans A G and Davidge R W 1970 J. Mater. Sci. 5314

Heinrich J 1987 Adv. Ceram. Mater. 2239

Jack K H and Thomson D P 1976 Progress Report No. 11, Ministry of Defence Contract AT/2043/028/ AML, USA

Jennings H M, Dalgleigh B J and Pratt P L 1978 Ber. Deut. Keram. Ges. 55394

Mclean A F 1982 Am. Ceram. Soc. Bull. 61861

Mukerji J, Das P K, Bandopadhyay S, Rakshit J, Chakraborty D and Mukhopadhyay A K 1985 4th Report, Ministry of Defence, Grant No. AERO/RD-134/100/10/81-82/296

Mukerji J and Rakshit J 1988 Ceram. Int. 14181

Noakes P B and Pratt P L 1972 Special Ceram. 5 (ed.) Popper p. 299

Parr N L and May E R W 1967 Proc. Br. Ceram. Soc. 781

Thomson D S and Pratt P L 1966 Proc. Br. Ceram. Soc. 637 